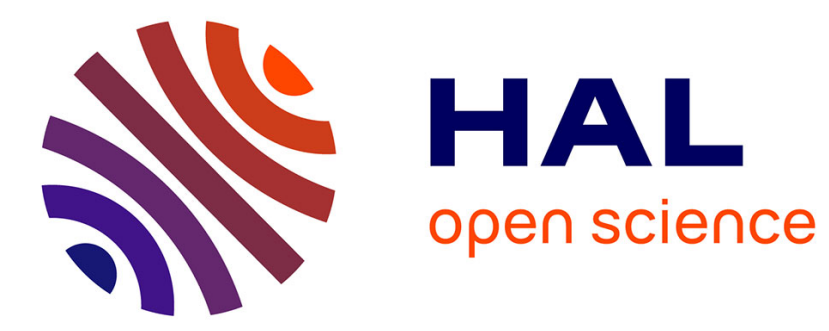

\title{
Cooperative Dynamics During the Financial Crisis: Evidence From Basque and Breton Case Studies
}

Lorea Narvaiza, Cristina Aragon, Cristina Iturrioz, Julie Bayle-Cordier, Sandrine Stervinou

\section{> To cite this version:}

Lorea Narvaiza, Cristina Aragon, Cristina Iturrioz, Julie Bayle-Cordier, Sandrine Stervinou. Cooperative Dynamics During the Financial Crisis: Evidence From Basque and Breton Case Studies. Nonprofit and Voluntary Sector Quarterly, 2017, 46 (3), pp.505-524. 10.1177/0899764016661775 . hal-01414168

\author{
HAL Id: hal-01414168 \\ https://hal.science/hal-01414168
}

Submitted on 12 Dec 2016

HAL is a multi-disciplinary open access archive for the deposit and dissemination of scientific research documents, whether they are published or not. The documents may come from teaching and research institutions in France or abroad, or from public or private research centers.
L'archive ouverte pluridisciplinaire HAL, est destinée au dépôt et à la diffusion de documents scientifiques de niveau recherche, publiés ou non, émanant des établissements d'enseignement et de recherche français ou étrangers, des laboratoires publics ou privés. 


\section{Cooperative dynamics during the financial crisis: evidence from}

\section{Basque and Breton case studies}

\section{Authors}

Dr. Lorea Narvaiza

Department of Marketing - Deusto Business School - University of Deusto

Mundaiz, 50

20012 San Sebastián, Spain

Phone: +34-943326298

Fax: +34-943292635

lorea.narvaiza@deusto.es

Dr. Cristina Aragon (Corresponding author)

Department of Strategy and Information Systems - Deusto Business School - University of Deusto

Mundaiz, 50

20012 San Sebastián, Spain

Phone: +34-943297275

Fax: +34-943292635

cristina.aragon@deusto.es

ORCID iD: 0000-0002-2596-9104

Dr. Cristina Iturrioz

Department of Strategy and Information Systems - Deusto Business School - University of Deusto

Mundaiz, 50 
20012 San Sebastián, Spain

Phone: +34-943326600

Fax: +34-943292635

cristina.iturrioz@deusto.es

ORCID iD: 0000-0001-5182-1894

Dr. Julie Bayle-Cordier

Management Department - IESEG School of Management

LEM-CNRS

1 Parvis de la Defense, 92044 Paris la Défense, France

Phone.: +33-155911010

Fax : +33-147759375

j.bayle-cordier@ieseg.fr

Dr. Sandrine Stervinou

Department of Strategy - Audencia Nantes - School of Management

8 Route de la Jonelière

BP 31222

44312 Nantes cedex 3, France

Phone: +33-240373443

Fax: +33-240373407

sstervinou@audencia.com 


\section{Author(s)' Note}

Thanks are due to the cooperatives' leaders and members that have provided the required evidences for this paper. We also thank to Roger Spear for his inspiring comments. Additionally, we acknowledge financial support from the Basque Government Department of Education Language Policy and Culture.

\section{Keywords}

non-for profit organizations, cooperatives, degeneration, regeneration, crisis. 


\begin{abstract}
In the recent financial crisis period, when traditional economic organizations were not able to meet stakeholders' expectations, not-for profit organizations such as cooperatives became an optimal solution as they are expected to serve social and economic performance simultaneously. This theoretical assumption is questioned based on the downturn pressures that may weaken cooperatives' social performance in favor of economic performance. This degeneration process (Cornforth, et al., 1998) is countered by some traditional cooperatives that have developed regeneration dynamics. The aim of our study is to explore how small and medium cooperatives face degeneration and develop regeneration dynamics in periods of crisis. To fulfil the objective of the paper four small and medium Basque and Breton cooperatives are studied in depth.
\end{abstract}




\section{Introduction}

The 2008 financial crisis struck communities around the world, creating the need for alternative initiatives and organizations to overcome the difficult outcomes in the market (Vieta et al., 2015). A solution may be found in not-for profit organizations, particularly in cooperatives, as these firms simultaneously consider as part of their mission, employee participation and satisfaction, community welfare and sustainability (Birchall \& Ketilson, 2009; Birchall, 2013). To fulfil their mission, cooperatives must balance economic and social concerns (Bagnoli \& Megali, 2011). However, financial crises may threaten cooperative values, hinder democratic principles in favor of market interests, and foster a degeneration process, which may lead to the failure of such democratic organizations in the long run (Cornforth, et al., 1988). The question for democratic organizations is how to maintain their mutual character when facing changes. As Storey et al. (2014) state, the degeneration into capitalist form of business has been analyzed in the literature for almost a century (Meister, 1974, 1984). In some cases, a regeneration of cooperative principles is attained, and a new equilibrium is found.

The literature has analyzed the cooperatives' degeneration and regeneration thesis (Batstone, 1983; Cornforth, 1995; Conforth et al., 1988; Hernandez, 2006) and demutualization and mutualization (Sousa et al., 2012). In particular, Mondragon, a Spanish business group integrated by autonomous and independent cooperatives, has been studied as a relevant case (Bakaikoa et al., 2004; Arando et al., 2010; Storey et al., 2014). Some studies focus on large cooperatives' failure (Fulton \& Larson, 2009; Couchman \& Fulton, 2015) but surprisingly little work has focused on small and 
medium cooperatives. Following $\mathrm{Ng} \& \mathrm{Ng}$ (2009) small and medium coops face specific costs for maintaining democratic principles with efficiency and even leadership (e.g., the time and energy involved in training, long meetings to reach decisions, time dedicated to prepare transparent information, ideological resistance to leadership and management, inconsistencies in policies attempting to accommodate personal circumstances). These specificities can influence the degeneration-regeneration process, thereby making regeneration dynamics more difficult to achieve, yet making its analysis all the more interesting and relevant.

Our aim is thus to explore how small and medium coops from different geographical settings face degeneration and develop regeneration dynamics in periods of crisis. We adopt an in-depth case study approach of four selected small- and medium-sized French worker cooperatives (Société coopérative de production-Scops) and Spanish labor cooperatives. The contributions of this paper are threefold. First, from an academic perspective, this study illustrates how degeneration is expressed in small and medium coops in different contexts; second, heterogeneous regeneration processes are identified as dependent on the competitive position of the cooperative in the degeneration process. Third, for practitioners, the four case studies provide an empirical stepping stone to identify and assess the key dynamics developed by small and medium coops in the degeneration-regeneration processes.

First, cooperatives' degeneration and regeneration dynamics are discussed. Second, the selected methodology is presented. Third, the two Basque and two Breton small and medium coops' regenerative dynamics that respond to degeneration processes are extracted. Finally, the discussion is presented. 


\section{Cooperatives' degeneration-regeneration dynamics}

Following Poledrini (2015), cooperative firms may be defined as a type of social enterprise. These democratic organizations, with a social component rooted in cooperative principles and values, serve their members' interests (Novkovic, 2008). There are approximately 90,000 worker and producer cooperatives in Europe (members of Cicopa; this excludes agricultural producer co-operatives). Within Europe, Spain and Italy have the greatest number of worker cooperatives, with approximately 31,500 and 54,200 enterprises, respectively. France and Poland, which follow Spain and Italy, have far fewer worker cooperatives with only 2,000 and 1,500 worker cooperatives, respectively (Corcoran and Wilson, 2010; Cicopa, 2013). In this research we will focus solely on worker cooperatives.

Although there are a wide range of legislative frameworks for cooperatives in Europe, a set of principles are common to these organizations: voluntary and open membership; democratic member control; economic participation by members; autonomy and independence; education, training and information; cooperation among cooperatives;

and concern for the community (ICA, 2016). Therefore, cooperatives are often seen as a way to promote the economic and social development of the regions and communities in which they are located (United Nations General Assembly, 2013). Two dimensions are expected to be balanced in cooperative societies: the business dimension, which is focused on strategically managing resources and capabilities to develop a sustainable position in an industry; and the social dimension of cooperatives, which aims to manage both internal and external stakeholders' interests (Mozas, et al., 2010). These 
dimensions exist in a dynamic and unstable equilibrium. The cooperative sector has frequently been marked by this isomorphic trend (Spear, 2004), and its specific values have been challenged.

This problem, which is not exclusive to cooperatives, has been explained by the degeneration thesis (Cornforth, et al., 1988). This thesis suggests that cooperatives fail as democratic organizations in the long run due to external or internal pressures.

Moreover, the different strands of degeneration theory have been categorized into three types (Cornforth, et al., 1988). First, formal or constitutional degeneration may occur when cooperatives revert to a capitalist form in which membership is restricted. In this case, employees are hired to secure a greater proportion of the surplus to partners (Spear, 2004). This situation leads to some workers losing certain democratic rights that originally applied to all, such as membership rights (Arando, et al., 2010). Second, goal degeneration implies that cooperative goals are replaced by capitalist goals of profit seeking, diminishing the social perspective of the organization. In this case, the cooperative becomes similar to a capitalist business. Finally, the third organizational degeneration happens when the participatory structure and, as a result, the cooperative control becomes concentrated in the hands of a dominant elite. This degeneration can be the result of the low worker participation or due to the natural organizational growth process (Bakaikoa, et al., 2004, Couchman and Fulton, 2015).

As a reaction to degeneration, regenerative dynamism may occur. This process has been illustrated by Batstone's (1983) three-staged life cycle model. In this model, after a first step of initial enthusiasm and a second step of the decline of primitive democracy, a third stage of "resurgence of democracy" closes the loop of the cycle. In this sense, 
Hernandez (2006) also considers the cooperative as a context for ongoing tension between oligarchic and democratic forces. Due to its inherent instability, ongoing dissatisfaction with the achieved balance is required (Storey et al., 2014). Equilibrium may be reached through an ongoing dynamic process.

In crisis periods, small and medium coops have to manage organizational resources, structures and dynamics that allow for social and economic resilience (Cheney et al., 2014). Following the classification of influences proposed by Sousa et al. (2012) for demutualization and mutualization, internal and external influences are considered. Related to the internal -human and organizational- elements, first, we study the member's involvement and the related economic linkage, understood as the shared collective identity and common goals that can shift from cooperative services to financial gains. As Storey et al. (2014) state, in large cooperatives, regeneration occurs when the organization displays a culture of open criticism and discussion (Cornforth, 1995) and when an active and explicit commitment of members takes place. To reach this state, some continuous effort is required to (1) support the internalization of democratic principles among the old and new members (Sousa et al., 2012); (2) maintain participation; (3) reduce the knowledge power gaps between members; (4) preserve collective interest above self-interest, mainly by informal leaders; and finally, avoid conflict suppression ( $\mathrm{Ng}$ and $\mathrm{Ng}, 2009)$. Therefore, the capacity to reinvent a weak democracy, and reinvent it democratically, is a key factor in this context (Cheney et al., 2014). Second, the role of organizational leaders, to convince others that the change is best for everyone involved (Sousa et al., 2012), and to manage the tension between worker-member power and managers' oligarchic tendencies is evident (Hernandez, 2006). The role played by informal leadership is under-recognized in small 
cooperatives ( $\mathrm{Ng}$ and $\mathrm{Ng}, 2009)$. Therefore, strong governance structures supporting leaders and balancing cooperative efficiency and members' requirements are key to foster regeneration processes. However, the maintenance of cooperative values and support for pertinent leadership are challenged by organizational factors, such as the growth trajectory and the life cycle of the cooperative (Sousa et al., 2012).

Regarding external influences, two readings may be considered. First, cooperatives adapting to external changes, such as a macroeconomic crisis, may degenerate due to the changing and demanding market requirements; but they can also regenerate, if this context provokes the desire to change the environment or to participate in a broader social movement (Sousa et al., 2012). In these cases, the regeneration process often requires the creation or the recovery of an identity, an intense task that can require some kind of external assistance. In this sense, outside agencies can play a relevant role in regeneration processes (Sousa et al., 2012).

Considering the combined effect of these influences, the question that arises is how cooperatives can support both commercial and social goals, particularly during a crisis period. In our study, we seek to analyze how cooperatives maintain their competitiveness and social components simultaneously during crisis periods and considering contexts where this degeneration process has already been identified (Spear, 2004). In other words, we focus on how small and medium coops face cooperative degeneration and balance both economic and social dimensions in order to regenerate. 


\section{Methodology}

The selection of the cooperatives for this study was guided by the possibility of illustrating different strategies concerning the survival of the organization and the cooperative principles trade-off.

[Table 1 Here]

We gathered data from each company over a period of five years, 2011-2016. We focused on the founder or leader of each small and medium coop as we consider them to be legitimate to speak on behalf of their organization. In small and medium coops such as the French worker cooperatives (Scop) or the Spanish labor cooperatives, the leader is elected democratically by employees to exercise his/her mandate and implement a strategy that is voted on by all. This unique governance gives more legitimacy to the leader in terms of embodying an authentic organizational identity and avoiding the pitfalls of leaders who may seem hypocritical in seeking to express an ideal rather than an actual organizational identity (Balmer \& Greyser, 2002). In some cases (EB, M) we also interviewed workers in order to gather their point of view and for triangulation purposes. To increase validity of interviewee claims, we triangulated our data sources and particular attention was devoted to the actions described by managers.

[Table 2 Here] 
To guarantee reliability, we followed several recommendations (Yin, 2003). First, to establish a formal protocol of the case, we defined the generic purpose of the study case, the procedure for gathering the data and the interview guide. A database containing all of the empirical evidence was established to collect all of the documents required to elaborate the final case report. The construct validity was ensured by the use and triangulation of various sources of evidence and the contrast of the results with the key informant from each case (Yin, 2003). The chain of evidence was constructed from press items, each cooperative's web site, and detailed face-to-face interviews with the leader or one of the managers of each cooperative, and in some cases a worker (EB, M). Internal validity was ensured by the design of a dedicated framework, based on the relevant literature and preliminary assumptions. External validity, which analyzes four cases, was confirmed. Our case study research carries out analytical generalization in which particular findings are generalized into a broader theory (Yin, 2003). After conducting an exploratory field study in both Spain and France, we selected four cooperatives (two Basque, two Breton) to illustrate the degeneration-regeneration phenomenon which we uncovered in doing this study. We chose a small (less than 50 employees) Basque (G-43 employees) and Breton firm (LC-15 employees) and a medium (less than 250 employees) Basque (EB-170 employees) and Breton (M-200 employees) firm. Two of the cooperatives were founded in the mid-70s (LC-1975, EB1977) and the two others in the mid-80s (G-1986, M-1986). The firms selected for our study showed signs of some kind of degeneration process. Actually one of the described four cooperatives (LC) changed its ownership structure and demutualized.

[Table 3 Here] 


\section{Findings}

\section{Basque cooperatives, Northern Spain}

The Basque Cooperative movement is not only a substantive part of the basque economic fabric but also part of the basque culture. Konfekoop, the Basque Cooperatives Confederation, encourages the promotion of the cooperative movement and nowadays, represents more than 1.000 cooperatives in the Basque Country. A paradigmatic example of the relevance of basque cooperativism is the Mondragon Group, one of the leading business groups in the Basque Country (Zelaia, 2011; Iturrioz et al., 2015). Mondragon is a new organizational paradigm based on a dual employment model wherein, apart from the cooperatives themselves, there are conventional companies dependent on the former Mondragon (Jones \& Kalmi, 2012; Bakaikoa, et al., 2004). From this group, consultants, organizations, technological centers and a university have been created in the region, supporting and enhancing the cooperative principles in their activities. Apart from the well know Mondragon experience there are other initiatives in the Basque Country such as NER group (Ner, 2016). This group is an association in which diverse organizations, united by the New Style of Relationships, share experiences, synergies and knowledge to improve performance, and accompany each other on the path towards profound cultural change entailed by this (NER) style. This association has a clear concern for society, with the goal to achieve a just and sustainable human development. In short, the Basque region has a dynamic and strongly supported cooperative system due to rich institutional and historical support. 


\section{Cooperative EB}

EB was created in 1977 by employees who were fired by a company that went bankrupt. Six young people in their early twenties decided to create a cooperative to make a similar product to the one they had been making in their previous firm. Today, EB has 170 employees and is a member of Mondragon. The mission of the cooperative is as follows (co-founder, $25^{\text {th }}$ of April 2013):

"By supplying electrical conductors and providing innovative solutions that give added value to our customers, our mission is to develop a company that, through the generation of profits and the satisfaction of people, society and the surrounding area, is able to grow in a stable and sustainable manner through a corporate model based on responsible people."

This is a two-part mission with an economic component (the generation of profits) and a social aspect (the satisfaction of people, society and the surrounding area). In the words of one of the founders (co-founder, $25^{\text {th }}$ of April 2013),

"The mission of a cooperative is first to generate profits and to create jobs; you have to earn money and look for profitability by creating jobs and harmony with people."

However, democratic governance has been a challenge over time as the cooperative has grown in size (cofounder, $25^{\text {th }}$ of April 2013):

"When we started 38 years ago, we were very small among terrible monsters. Competition was high, flexibility was zero and they gave the client not what he wanted but what they had. We started to earn money in six months, but it was 
very demanding... If it had not been a cooperative, we would not have done this. You do it because it is yours. When you grow, this disappears... When you grow, the feeling of being the owner is lost. The firm's size means a lot."

The feeling of ownership and the challenge of surviving was very strong in the early stages of the cooperative's existence. As the cooperative grew and new young members arrived, the sense of belonging was not as easy to maintain and member's commitment began to wane. In order to recover the cooperative spirit, external help such as psychologists and other external consultants were used (cofounder, 25 ${ }^{\text {th }}$ of April 2013): "From the beginning, we had an innovative attitude, an innovative spirit, and we tried to offer constant improvements to our clients. [...]Usually when you grow, the ownership spirit disappears. To make this change and promote a cooperative spirit, we have been working with psychologists and other professionals for 2-3 years. We have had external help to meet with different group of workers. If you do not have external help, you do not achieve your goals."

Management expertise is critical and necessary to adapt to the changing environment (both internally and externally), to be competitive and to keep the fundamental guiding principles of the cooperative alive (cofounder, $25^{\text {th }}$ of April 2013):

"The CEOs must be in tune with the cooperative. Normally, they are managers from the cooperative. If the $\mathrm{CEO}$ and top managers do not fit, no one fits. In our case, it used to be from the inside. We now have a CEO who came from another cooperative. And he is very committed." 
The new CEO had management experience in other cooperatives of the Mondragon group and his commitment helped to recover the cooperative spirit among members (worker, $12^{\text {th }}$ of May 2015):

"We are involved now in activities such as visiting clients to make sense of the work we do. But we also have the capacity to organize events such as "open doors" for family and friends."

The social and democratic aspects are not incompatible with being competitive. In 2015 the firm was awarded the prize "Industrial SME 2015" in its region, Gipuzkoa. The reason was to recognize its people management model, its internal organization, its strategic vision, its teamwork and its internationalization. Now the governance and the cooperative principles are aligned.

\section{Cooperative G.}

Cooperative $\mathrm{G}$ designs, manufacturers, markets, installs and provides after-sales service for bakery ovens. The company has 43 employees. The situation was as follows (president, $9^{\text {th }}$ May 2013):

"The firm was going down because it was mainly centered in Spain, and the market was dead. In the last few years, we were being dragged down by the economic situation, and we had several years of significant tension (the lowering of wages); the cooperative spirit was disappearing... and then the labor climate was deteriorating."

"We have started working with a consultant and his team. This consultant and his team have helped us promote and re-ignite the cooperative spirit. Once a 
pyramidal structure, we are now a horizontal firm where we have created work teams with leaders to involve the entire team. We wanted fresh air."

This cooperative has begun an internal change process with the help of the external consultant who has experience with cooperatives. After initiating an internal change process to revive their founding cooperative spirit and values, giving more autonomy to their employees and making a more horizontal structure, the founders have taken a step further by integrating the cooperative into NER group. NER group is an association in which diverse organizations, united by the New Style of Relationships, share experiences, synergies and knowledge; join forces to improve, advance, be more efficient, and get better results, and accompany each other on the path of profound cultural change entailed by this (ner) style. It is an association with a clear concern for Society, which wants to achieve a Just and Sustainable Human Development. The president of Cooperative G. explains the motivation behind this decision (president, $9^{\text {th }}$ May 2013):

"This group is an association in which diverse enterprise organizations, linked by the New Style of Relationships, share experiences, synergies and knowledge; joint efforts to improve, advance, be more efficient and obtain better results; and they share the path of deep cultural change to apply the New Style of Relationships (Ner)".

To overcome a difficult economic situation for their firm and improve the work climate, this cooperative attempted to renew with its cooperative spirit and its principles through, first, an internal change process (with the help of an external consultant), and second, by collaborating with a group of firms with similar values and objectives. NER helped the firm reach a critical size in order to negotiate with suppliers, such as banks, and also to reinforce their spirit for cooperation, with other firms and with society. 


\section{Breton cooperatives, Western France}

The Western Regional Union of Scop includes cooperative and participatory societies ("sociétés cooperative et participative") of the 12 departments of three regions (Brittany, Pays de la Loire and Lower Normandy) adherent to the General Confederation of Scop. In these regions, there are 386 cooperative firms (Société coopérative de productionScop and Société Coopérative d'intérêt Collectif-Scic). In the region of Brittany, considered in our study, there are 193 Scop and Scic (Les Scop, 2016).

Network of West Scop is a place of exchanges, entertainment and information that accompanies all Western Scop. It consolidates cooperative life through: support leaders, the partners' liability, the animation of the collective, welcoming new partners, approving group projects, and so on. Brittany has a well-supported cooperative system and a rich institutional and historical backing. In particular, the two firms studied are very involved in the Scop network and are very conscious and proud of their cooperative status.

\section{Cooperative $M$}

In Brittany, the Scop M. was created ex nihilo in 1986 as a personal search to bring together the notions of "entrepreneur" with that of "co-operative activist" within the same firm. In the words of the executive director (cofounder and executive director, 22nd November 2011),

"In 2000, we were thirty, and today, we are one hundred and fifty. Just before 2000, it was a difficult time: three of the four founders of the firm left. The employees were activists; we all had almost the same salary. [...] There were 
two firm projects in discussion, which were always done democratically. We had the help of a consultant. Eighty percent of the thirty employees at that time agreed with my proposals. That is how I became the general manager. At that time, I talked about growth, having a cooperative spirit without losing our origins, our values."

The cooperative spirit was present in the beginning but as time passed and the firm grew, the cooperative principles became less well-known by some of the new workers. A few years ago, some of the founders did not want to grow, whereas the actual CEO defended growth and the creation of jobs as a way to survive. Some of the founders left the firm because they did not agree with the growth strategy, but the majority of employees followed the current CEO. This change process was overseen by an external consultant.

Regarding the importance of keeping the social aspect balanced with the economic aspect (cofounder and executive director, $22^{\text {nd }}$ November 2011),

"The people are very committed. It is very important to give meaning to one's work. $[\ldots]$ We are not born members [of the cooperative]; we become members. And in our firm, we need to cooperate and make things together."

For the senior manager, people's responsibility ("self-management") and employees' competences are very important. In this sense, training is relevant for them (cofounder and executive director, $22^{\text {nd }}$ November 2011):

"I am a defender of everything that elevates people in their knowledge. Today, the firm has decided to invest $5 \%$ of the "gross salary" into training. It is a political choice. All employees have professional and cooperative training." In the Scop, maintaining the cooperative spirit is orchestrated by providing training to employees and sharing their values in everyday decisions. Regarding the objectives and 
the mission, the cofounder and current executive director explained $\left(22^{\text {nd }}\right.$ November 2011):

"For $\mathrm{M}$ and me, the social and economic aspects are equally important. It is 50-

50. We have an activist dimension to our firm. We want to show that there is another way of relating to work apart from what we see today."

The economic mission is considered important for this Scop to ensure the sustainability and self-reliance of the organization (cofounder and executive director, $22^{\text {nd }}$ November 2011):

"The firm has been almost 100\% self-sufficient. The members have been given money for new projects by banks and a very small amount from the region. So, the firm is very independent."

The cofounder, a strong leader, has been present from the beginning. Regarding democratic and harmonious governance, worker participation at all levels of the firm is relevant but not always harmonious. Three of the four founders left the company fifteen years ago. The firm is financially independent and continues to reinvest its own capital into the development of the firm. The firm grew very fast and some signs of degeneration have appeared recently (worker, July $2^{\text {nd }}, 2013$ ):

"We only vote, we are not inside the discussions, the executive director decides a lot for us".

Now there are signs of unhappiness in the organization. Conflicts and lack of balance between efficiency and social and democratic behavior have become a new reality for the organization. 


\section{Cooperative LC}

LC was created in 1975 and it operates in the printing business. Cooperative LC was for the founders an alternative model to the traditional (investor owned) printing firms. The founders wanted to create a firm where employees could be autonomous and engage in self-management and where equality was a respected principle.

In 2011 it had 15 employees, all of whom were cooperative members, except for the person who had just joined four months previously. In the words of the coordinator, the mission of the cooperative is as follows (administrator, $7^{\text {th }}$ October 2011):

"The mission is maintaining jobs and offering a service to the clients according to their expectations. It is maintaining production here [in Western France], making ethical purchasing decisions. [...]. The first priority is the economic mission, then the social mission. We are a firm first — based on a social economy, but a firm first."

This Scop had to face difficult years, and the CEO explains the type of decisions that were made (administrator, $7^{\text {th }}$ October 2011):

"In 2009, we had to put into effect a restructuring plan for execution in 2010. [...] We were very much influenced by external consultants. We did not have enough confidence in ourselves. We had a very complicated year in terms of our internal elections and governance, firing, and communication. We have suffered from our governance structure, and it became very difficult. The consultant didn't realize how important the equilibrium that we had was so important to us. This balance was based on elements that were key for us, such as the equality of all salaries. It may appear to be trivial but the consequences that this had on our internal relationships was unimaginable. It isn't a question of numbers; it is a question of mutual respect and consideration among us." 
According to the leader-coordinator of the Scop (leader-coordinator, $7^{\text {th }}$ October 2011), "There were fewer opportunities for discussion. I think that at a certain time, the old and new members had to talk more. We had to understand each other better between different generations."

The company's democratic way of governing was not sufficient to keep employee morale high. The administrator explains (administrator, $7^{\text {th }}$ October 2011),

"We decided by majority vote. It was hard because a majority of $83 \%$ is not enough; it is not sufficient to unite. There were two people who voluntarily agreed to leave. This caused an earthquake. [...] This provoked anguish, but this was already there when the result accounts went down in the spring of 2009. At that moment, we didn't react on our own. The external help that arrived in the autumn of 2009 was maybe a bit too late because we were already very vulnerable."

Facing the crisis, the managers neither reacted quickly enough nor were confident enough, and they had to look for external help a few months later. Although democracy was part of their governance, harmony in the firm was broken when they came to the decision to dismiss people. Although the process was participatory, some decisions suggested by the external consultant did not fit with certain Scop principles.

To have access to financial resources, they had to accept a change in their governance structure (administrator, $7^{\text {th }}$ October 2011):

"The financial partners wanted to lend us money if we had a general director to help us. The general director knew the world of Scops and the profession, but it did not work. [...] This general director stayed for 6 months, but he should have stayed for three or four more months. This had consequences for one year." 
The participation of an external CEO was difficult for members. The limitations of being a Scop were described as follows (administrator, $7^{\text {th }}$ October 2011):

"Some of the decision-making process seemed heavy, sometimes slow. The relationship with suppliers was sometimes a bit complicated because they didn’t know who the new company representative will be."

Decisions were made collectively and the firm was a social organization but the members were not able to adapt to the new situation and to take the needed decisions (administrator, February $3^{\text {rd }}, 2016$ ):

"The members and the cooperative culture and principles were more important than the firm survival, it was something sacred."

They had an opportunity to merge with another coop but they did not want to change their salary ratio, and other conflicts arose. Finally, a for-profit company acquired them and 6 out of 15 employees are now working in the new company. The employees who left refused to work for the new organization because it was like "being bought by the enemy (capitalism)".

\section{Discussion and conclusions}

Our study sought to understand how cooperatives manage business and democratic tensions (Jones and Kalmi, 2012), particularly in times of economic crisis and in a dualcountry context (Spain and France). Four co-ops that faced the economic crisis are analyzed from the degeneration-regeneration lense. The paper's contribution is threefold. First, it illustrates how degeneration and regeneration processes evolve in small and medium coops in different contexts. Second, heterogeneous regeneration processes are identified depending on the competitive position of the cooperative in the 
degeneration process. Particularly relevant is the institutional support to social economy existing in the broader societal context. Finally, identifying the key dynamics developed by small and medium coops in the degeneration-regeneration processes, the four case studies provide an empirical stepping stone for the practical assessment of these dynamics.

Relating to the heterogeneity in the degeneration process, two groups can be identified depending on the competitive position of the small and medium coop. On the one hand, we find degeneration in competitive cooperatives (DCC), such as M and EB. These cooperatives develop product innovations and have a strong growth trajectory. As a consequence the growth and the focus on external market requirements reduces the internal organizational care for preserving the social component and allows degeneration to progress. The abdication of the governance structure in supporting the cooperative principles, allows the market to prevail over organizational democracy (EB), and/or divides the governance members, between social defenders and growth (and social) defenders (M). Recently, there is also in $\mathrm{M}$ an organizational degeneration since some workers perceive that the cooperative control is too concentrated in the hands of the charismatic leader. So in these two cases (EB, M) the business and social equilibrium has changed over the years and has reached an unstable state that must be reestablished.

On the other hand, we find degeneration in noncompetitive cooperatives (DNCC), such as LC and G. These organizations are not internationalized and face a declining national market. In the context of economic crisis, the cooperative principles of these cooperatives fade $(\mathrm{G})$ or are challenged by capital requirements (LC) while losing 
ground in their market. In this group external influence dilutes the social component of the cooperative that is at risk of failure. In addition to the internal decisional problems of reaching consensus, leadership problems arose in LC and contributed to make the coop disappear. Degeneration has different consequences depending on the position of the company in the market. While both groups (DCC and DNCC) display degeneration, the second group is more vulnerable to degeneration due to the additional market problems. Anyway, even when competitive pressure does not exist, internal issues have to be faced.

Regarding the regeneration process, conditions are different for each group of cooperatives. In the case of DCC, both cooperatives have chosen to recover their social component without reducing their competitiveness. The balancing of both components required external and specific assistance. Thanks to this assistance, leaders may promote a cooperative culture by exploiting its potential engagement and commitment power. The success of the cooperative is heavily dependent on both managerial expertise and his/her understanding of cooperative culture; and the alignment of the managerial and the governance purposes. In the Spanish case (EB), the leader has managerial expertise and promotes the democratic and harmonious governance of the cooperative. In the French case (M), first, training the governing group is emphasized, thus avoiding the lack of participation by the owners in decision-making processes (Chizema, 2011; Couchman \& Fulton, 2015) and thus gathering all cooperative members around the business project, avoiding internal divisions. But again, recently some organizational degeneration has appeared and again balance needs to be reestablished. This condition of trying to recover the social component is shared in both groups (DCC and DNCC). In fact, in the four cases, in addition to articulating the process of gathering information 
and participation in the decision-making process, the governance focuses on the collective appropriation of the business project, the enhancement of mutual recognition and trust, and building social links, understood as 'the willingness and ability to define collective goals that are then enacted collectively' (Leana \& Van Buren, 1999: 542).

In the case of DNCC, the uncertain context, such as the economic crisis period challenges the regeneration process. The vulnerable economic situation requires a leader with both: a strategic vision, dynamic capabilities developed to address changes and manage tensions between long- and short-term decisions (O'Reilly \& Tushman, 2008); and work on recovering the original commitment and engagement of employees. Therefore, finding leaders with managerial expertise is not an easy task for declining organizations, and not all managers can succeed in a cooperative context. In the G case, the cooperative hired the coaching expertise of a consultant group with cooperative sensitivity and experience and deep knowledge of its context. Consequently, the cooperative identity was enhanced and it is considered now a successful experience. In other cases, due to the lack of managerial expertise (LC), it is not unusual for small and medium coops to hire an external manager with the aforementioned social sensitivity and managerial skills. LC followed the advice of an external consultant who was not sensitive enough to the specificities of the cooperative. The decisions made as a result of his advice are now considered a mistake because the recommendations ignored the relevance of some key cooperative principles, and thus the market criterion was privileged to such an extent that the cooperative values degenerated (Cornforth et al., 1988). The effect on internal relationships could not have been foreseen, and the cooperative needed a full year to overcome the negative consequences. Besides, under financial pressure, LC hired an external manager to help boost economic efficiencies in 
the cooperative, but he left the organization a few months later due to the lack of alignment between his methods and the cooperative principles. After a critical period of successive failed experiences, the owner-employees sacrificed their salary and this was decisive to foster a more resilient organization (LC). But to put forward the cooperative principles as non-negotiable has made the firm disappear. Thus, instead of being a means, to be a cooperative became an end in itself and the result is that LC does not exist anymore. Therefore, collective decision-making may sometimes be detrimental and even more so when the firm faces economic difficulties (Bataille-Chedotel et al., 2004).

In conclusion, in the case of degeneration in a noncompetitive cooperative (DNCC) it is common to seek external assistance, but not all assistance is suitable for such cases. Having access to consultants, coaches and assistance services with a particular sensitivity and experience in the cooperative field is a key condition to foster regeneration of cooperatives principles. In the Spanish context, the relevance of Mondragon and the rich cooperative ecosystem, provide an abundant number of managers and consultants who are familiar with the cooperative context. Other groups, such as NER group, with similar values and objectives, facilitate access to specialized assistance. On the contrary, the difficulty in finding a stakeholder with cooperative experience in the financial system was an obstacle for LC to regenerate, and the inability to adapt finally made LC disappear. In order to face economic crises, social organizations need a supporting network of consultants, financial agents and policy makers who are able to understand this particular organizational model and its idiosyncrasies. Otherwise, in the absence of such a rich cooperative ecosystem, capitalist criteria are applied thus eroding the social roots of these organizations. 
[Table 4 Here]

The contribution of the paper is relevant for scholars, practitioners and for policy makers. For scholars we show how the degeneration of democracy within worker cooperatives may take place, considering heterogeneous processes. In addition, by focusing on the main dynamics developed by small and medium coops to reach this equilibrium in periods of economic crisis, we highlight the relevance of governance and management issues as drivers in this context (internal factors) and we include an additional institutional condition to some regeneration processes (external factor). The importance of balancing efficiency and social issues in a dynamic way is also highlighted for small and medium coops' survival. This study has relevance for practitioners as it highlights the need for the development of specific managerial and governance capabilities to ensure both sustainable growth and the maintenance of cooperative principles in worker cooperatives. A specific type of manager may be required to run a cooperative business - that is, a person who must be comfortable and adept at managing disequilibrium when they lead their companies through chaotic periods (Bayle-Cordier et al., 2015). Additionally, for policy makers it is important to highlight the role a rich cooperative ecosystem may play in enabling regeneration, thus allowing access to specialized assistance and empathetic dialogue with stakeholders. To conclude, managers, the governance body and policy makers are all key to attain longterm societal wellbeing and progress.

Indeed, the paper's main limitation is its case specificity based in four cases. Nevertheless, at this stage, important general lessons have emerged regarding the conditions that characterize regeneration dynamics to overcome degeneration trends. Repetition of the process will provide interesting data for researchers. 


\section{References}

Arando, S., Freundlich, F., Gago, M., Jones, D.C., \& Kato, T. (2010). Assessing Mondragon: Stability \& Managed Change in the Face of Globalization. The William

Davidson Institute, University of Michigan, working paper 1003, http://papers.ssrn.com/sol3/papers.cfm?abstract_id=1726449. Accessed February 1, 2016.

Bakaikoa, B., Errasti, A., \& Begiristain, A. (2004). Gobierno y democracia en los grupos empresariales cooperativos ante la globalización. CIRIEC-España, 48(abril). Bagnoli, L., \& Megali, C. (2011). Measuring performance in social enterprises. Nonprofit and Voluntary Sector Quarterly, 40(1), 149-165.

Balmer, J. M., \& Greyser, S. A. (2002). Managing the multiple identities of the corporation. Bradford University, School of Management.

Batstone, E. (1983). Organization and Orientation: A Life Cycle Model of French Cooperatives. Economic and Industrial Democracy, 4, 139-61.

Bayle-Cordier, J., Mirvis, P., \& Moingeon, B. (2015). Projecting Different Identities: A Longitudinal Study of the 'Whipsaw' Effects of Changing Leadership Discourse about the Triple Bottom Line. The Journal of Applied Behavioral Science, 51 (3), 336-374. Bataille-Chedotel, F., \& Huntzinger, F. (2004). Faces of governance of production cooperatives: An exploratory study of ten French cooperatives. Annals of Public and Cooperative Economics, 75(1), 89-111.

Birchall, J. (2013). The potential of co-operatives during the current recession; theorizing comparative advantage. Journal of Entrepreneurial and Organizational Diversity, 2 (1), 1-22.

Birchall, J., \& Ketilson, L. H. (2009). Resilience of the Cooperative Business Model in Times of Crisis. Geneva: International Labour Organization. 
Cheney, G., Santa Cruz, I. Peredo, A.M., \& Nazareno, E. (2014).Worker cooperatives as an organizational alternative: Challenges, achievements and promise in business governance and ownership. Organization, 1(21), 591-603

Chizema, A. (2011). The influence of ownership structure on the implementation of national codes of corporate governance: Development of research propositions. International Journal of Management, 28, 238-254.

Cicopa (2013). How cooperatives show resilience to the crisis, documentary by CECOP-CICOPA Europe (http://www.together-thedocumentary.coop) Corcoran, H. \& Wilson, D. (2010). The Worker Co-operative Movements in Italy, Mondragon and France: Context, Success Factors and Lessons. Canadian Worker Cooperative Federation.

Cornforth, C. (1995). Patterns of Co-operative Management: Beyond the Degeneration Thesis. Economic and Industrial Democracy, 16, 487-523.

Cornforth, C., Thomas, A., Spear, R., \& Lewis, J. (1988). Developing successful worker co-operatives. Sage Publications Ltd.

Couchman, P. \& Fulton, M. (2015). When big co-ops fail. Centre for the Study of Cooperatives, Plunkett Foundation. Available at: http://usaskstudies.coop/documents/pdfs/When\%20Big\%20Coops\%20Fail\%20FInal\%2003.11.2015.pdf. Accessed February 1, 2016.

Fulton, M. \& Larson, K. (2009). Overconfidence and Hubris: The Demise of Agricultural Co-operatives in Western Canada. Journal of Rural Cooperation, 37(2) 2009: 166-200. Available at http://purl.umn.edu/163812. Accessed February 9, 2016. Hernandez, S. (2006). Striving for Control: Democracy and Oligarchy at a Mexican Cooperative. Economic and Industrial Democracy, 27(1), 105-35. 
ICA (2016). Co-operative identity, values \& principles. Available at:

http://ica.coop/en/whats-co-op/co-operative-identity-values-principles. Accessed

February 9, 2016

Iturrioz, C., Aragon, C \& Narvaiza, L. (2015). How to foster shared innovation within SMEs' networks: Social capital and the role of intermediaries. European Management Journal, 33(2), 104-115.

Jones, D. C., \& Kalmi, P. (2012). Economies of Scale versus Participation: A Cooperative Dilemma? Journal of Entrepreneurial and Organizational Diversity, 1(1), 37 64.

Leana, C. R., \& Van Buren, H. J. (1999). Organizational social capital and employment practices. Academy of management review, 24(3), 538-555.

Les Scop, (2016). Available at: http://www.les-scop-ouest.coop/sites/fr/unionsregionales/les-scop-ouest/les-scop/qu-est-ce-qu-une-scop.html. Accessed February 14, 2016.

Mozas, A., Puentes, R. \& Bernal, E. (2010). La E-corporate Social Responsibility en las sociedades cooperativas agrarias andaluzas. CIRIEC-España, Revista de Economía Pública, Social y Cooperativa, 67, 187-212.

Ner (2016). Avalaible at: http://www.nergroup.org. Accessed June 15, 2016

Ng, C.W. \& Ng, E. (2009). Balancing the Democracy Dilemmas: Experiences of Three Women Workers' Cooperatives in Hong Kong, Economic and Industrial Democracy, $30,182-206$

Novkovic, S. (2008). Defining the co-operative difference. The Journal of SocioEconomics, 37(6), 2168-2177.

O’Reilly, C. A., \& Tushman, M. L. (2008). Ambidexterity as a dynamic capability: Resolving the innovator's dilemma. Research in Organizational Behavior, 28, 185-206. 
Poledrini, S. (2015). Unconditional reciprocity and the case of Italian social cooperatives. Nonprofit and Voluntary Sector Quarterly, 44(3), 457-473.

Sousa, J., Pattison, D., \& Herman, R. (2012). Thematic exploration and looking forward, in Sousa, J., \& Herman, R. (ed.). A co-operative dilemma, Centre for the Study of Co-operatives, Saskatton, Canada, 271-310.

Spear, R. (2004). From co-operative to social enterprise: trends in European experience in Borzaga, C., \& Spear, R. (eds.). (2004). Trends and challenges for Co-operatives and Social Enterprises in developed and transition countries. Trento: Edizioni 31.

Storey, J., Basterretxea, I., \& Salaman. G. (2014). Managing and resisting 'degeneration' in employee-owned businesses: A comparative study of two large retailers in Spain and the United Kingdom. Organization,21 (5), 626-644.

United Nations General Assembly (2013). Cooperatives in Social Development (Resolution adopted by the General Assembly on 18 December 2013). Available at: http://daccess-ddsny.un.org/doc/UNDOC/GEN/N13/447/43/PDF/N1344743.pdf?OpenE Lement

Vieta, M. \& Lionais, D. (2015). The cooperative advantage for community development. Journal of Entrepreneurial and Organizational Diversity, 4(1), 1-10. Yin, R.K. (2003). Case study research, design and methods, vol. 5, 3rd edition. Sage Publications, Thousand Oaks, California.

Zelaia, A. (2011). Spain: entrepreneurial cooperation in the regions, Zevi A., Zanotti, A. Soulage, F., Zelaia, A.(ed.) in Beyond the crisis: Cooperatives, Work, Finance. Cecop publications. 


\section{Short Biographical Paragraph}

Lorea Narvaiza is an associate professor in the Department of Marketing, University of Deusto (Spain). Her research interests focus on SMEs and cooperatives. In particular, she studies SR in SMEs and cooperatives. She teaches marketing at the University of Deusto.

Cristina Aragon is an associate professor in the Department of Strategy and Information Systems, University of Deusto (Spain). Her research interests focus on SMEs and different capital structures. Moreover, she is interested in the competitiveness of family firms and cooperatives.

Cristina Iturrioz is an associate professor in the Department of Strategy and Information Systems, University of Deusto (Spain). Her research interests focus on SMEs, innovation and cooperation. Moreover, she is interested in the competitiveness of SMEs and the cooperation. Currently, she is vice-rector of the University of Deusto.

Julie Bayle-Cordier is assistant professor in the Management Department, IESEG School of Management, Catholic University of Lille (France). Her research interests focus on hybrid organizations such as for profit firms with strong social missions and worker cooperatives. She teaches strategy and business ethics at IESEG School of Management in Paris. 
Sandrine Stervinou is an associate professor in the Department of Strategy, Audencia Nantes - School of Management (France). Her research interests focus on companies and territories, principally on the anchorage side of companies. More specifically, she is interested in social economy and especially worker cooperatives.. 
Tables

Table 1. Description of the cooperatives

\begin{tabular}{|c|c|c|c|c|c|}
\hline Cooperative & Year of creation & $\mathbf{N}^{\mathbf{0}}$ of employees & \% of members & Activity & Territory \\
\hline EB & 1977 & 170 & $90 \%$ & Copper wire & Basque \\
\hline G & 1986 & 43 & $81 \%$ & Baking equipment & Basque \\
\hline M & 1986 & 200 & $60 \%$ & Preton & Breton \\
\hline LC & 1975 & 15 & $81 \%$ & & Printing \\
\hline
\end{tabular}

Source: own elaboration 
Table 2. Description of the key informants

\begin{tabular}{|c|c|c|c|c|}
\hline $\begin{array}{l}\text { Name of } \\
\text { cooperative }\end{array}$ & $\begin{array}{l}\text { Key informants } \\
\text { name }\end{array}$ & Type of Source & Interviewee' Description & Description of the evidence \\
\hline EB & $\begin{array}{l}\text { SME Industrial } \\
\text { Cooperative }\end{array}$ & $\begin{array}{l}\text { Semi-Structured } \\
\text { interview }\end{array}$ & $\begin{array}{l}\text { C.Z.: Cofounder and ex-Top } \\
\text { Executive Director with more } \\
\text { than } 20 \text { year experience in top } \\
\text { positions within this MCC } \\
\text { cooperative } \\
\text { P.M: worker with more than } 10 \\
\text { years of experience in the firm }\end{array}$ & $\begin{array}{l}\text { Interview audio taped on the } 25 \text { of April of } 2013 \\
\text { Transcription of the interview of } 2294 \text { words } \\
\text { Interview audio taped on the } 12 \text { of May of } 2015 \\
\text { Transcription of the interview of } 1356 \text { words }\end{array}$ \\
\hline G & $\begin{array}{l}\text { SME industrial } \\
\text { cooperative }\end{array}$ & $\begin{array}{l}\text { Semi-Structured } \\
\text { interview }\end{array}$ & $\begin{array}{l}\text { I.G.: President of the } \\
\text { cooperative with more than } 14 \\
\text { years as member of the } \\
\text { cooperative }\end{array}$ & $\begin{array}{l}\text { Interview audio taped on the 9th May of } 2013 \text { in the firm facilities } \\
\text { Transcription of the interview of } 2499 \text { words }\end{array}$ \\
\hline & & Direct & Visit to the facilities & Approx. 1 hour visit to the facilities on the 9th of May of 2013 \\
\hline
\end{tabular}




\begin{tabular}{|c|c|c|c|c|}
\hline & & Observation & & \\
\hline M & $\begin{array}{l}\text { SME industrial } \\
\text { cooperative }\end{array}$ & $\begin{array}{l}\text { Semi-Structured } \\
\text { interview }\end{array}$ & $\begin{array}{l}\text { S.B.: Cofounder and executive } \\
\text { director with more than } 25 \text { year } \\
\text { experience in this top position in } \\
\text { the cooperative. } \\
\text { S.G.: worker with more than } 6 \\
\text { years of experience in the firm }\end{array}$ & $\begin{array}{l}\text { Interview audio taped on the Nov } 22 \text { nd } 2011 \text { in the firm facilities } \\
\text { Transcription of the interview of } 4.587 \text { words } \\
\text { Interview audio taped on the } 2^{\text {nd }} \text { of July } 2013 \text { in the firm facilities } \\
\text { Transcription of the interview of } 4417 \text { words }\end{array}$ \\
\hline LC & $\begin{array}{l}\text { SME industrial } \\
\text { cooperative }\end{array}$ & $\begin{array}{l}\text { Semi-Structured } \\
\text { interview }\end{array}$ & $\begin{array}{l}\text { F.F.: Coordinator of the } \\
\text { cooperative with more than } 3 \\
\text { years in the position } \\
\text { C.N.: Administrator of the } \\
\text { cooperative with more than } 24 \\
\text { years as a member }\end{array}$ & $\begin{array}{l}\text { Interview audio taped on the } 7^{\text {th }} \text { October } 2011 \text { in the firm facilities to F.F. and } \\
\text { C.N. } \\
\text { Transcription of the interview of } 5.842 \text { words } \\
\text { Interview to F.F. on the } 9^{\text {th }} \text { October } 2015 \\
\text { Notes taken during one and a half hour interview }\end{array}$ \\
\hline Mixed data & $\begin{array}{l}\text { Cooperative } \\
\text { Annual Reports }\end{array}$ & $\begin{array}{l}\text { Web based and } \\
\text { press reports }\end{array}$ & $\begin{array}{l}\text { Strategic Orientation and } \\
\text { Annual Results }\end{array}$ & Last five years \\
\hline
\end{tabular}




\begin{tabular}{|l|l|l|l|l|}
\hline & & and information & & \\
\hline Mixed data & Academic & Referred in the & Different articles regarding & Last ten years \\
& Articles about & Reference & degeneration, regeneration, & \\
& cooperative & Sections & cooperatives & \\
& & & & \\
\hline
\end{tabular}

Source: own elaboration 
Table 3. Summary of the structure of the interviews: Main dimensions and key issues

\begin{tabular}{|c|c|}
\hline DIMENSIONS & KEY ISSUES \\
\hline Interviewee Description & $\begin{array}{l}\text { - Interviewee's Position in the cooperative } \\
\text { - } \quad \text { Interviewee's experience in the cooperative context. }\end{array}$ \\
\hline Unit of Analysis Description & - $\quad$ Unit characteristics: main activities, size, structure, goals, results \\
\hline $\begin{array}{l}\text { The cooperative model and the } \\
\text { influence during the crisis }\end{array}$ & $\begin{array}{l}\text { - The mission, vision and strategic objectives } \\
\text { - } \quad \text { Evolution/Dynamic perspective: Key events or main stages } \\
\text { - } \quad \text { The cooperative model } \\
\text { - } \quad \text { Governance of the cooperative } \\
\text { - } \quad \text { How are decisions taken? }\end{array}$ \\
\hline $\begin{array}{l}\text { The cooperative principles and its } \\
\text { influence during the crisis }\end{array}$ & $\begin{array}{l}\text { - } \quad \text { The } 7 \text { cooperative principles } \\
\text { - } \quad \text { The influence of the cooperative principles during the crisis } \\
\text { - } \quad \text { Values in the cooperative }\end{array}$ \\
\hline $\begin{array}{l}\text { The social economic balance in the } \\
\text { cooperative }\end{array}$ & $\begin{array}{ll}\text { - } & \text { Evolution/Dynamic perspective: Key events or main stages } \\
\text { - } & \text { Priorities and reasons } \\
\text { - } & \text { Importance of economic and social issues and priorities }\end{array}$ \\
\hline The cooperative and the & - $\quad$ How are they paid? \\
\hline
\end{tabular}




\begin{tabular}{|c|c|}
\hline members/employees & $\begin{array}{l}\text { - } \quad \text { Differences between members and non-members? } \\
\text { - } \quad \text { Limits to non-members? }\end{array}$ \\
\hline $\begin{array}{l}\text { Cooperative and relationships to } \\
\text { other stakeholders }\end{array}$ & $\begin{array}{ll}\text { - } & \text { Main stakeholders } \\
\text { - } & \text { Advantages and disadvantages of being a cooperative towards the stakeholders }\end{array}$ \\
\hline Cooperative and innovation & - $\quad$ Examples of innovation \\
\hline Cooperative and leadership & $\begin{array}{ll}\text { - } & \text { Concept of leadership. Difference with non-cooperative firms. } \\
\text { - } & \text { Role of formal and informal leaderships } \\
\text { - } & \text { Styles of leadership } \\
\text { - } & \text { How decisions are taken? Centralization/Decentralization }\end{array}$ \\
\hline Cooperative and networks & $\begin{array}{l}\text { - Part of group or network of cooperatives? } \\
\text { - } \quad \text { Part of other types of networks? } \\
\text { - External consultants? }\end{array}$ \\
\hline Results achieved & $\begin{array}{l}\text { - } \text { Indicators used } \\
\text { - } \quad \text { Results obtained at the correspondent level } \\
\text { - } \quad \text { Results perceived } \\
\text { - } \quad \text { Evolution/Dynamic perspective: Key events or main stages }\end{array}$ \\
\hline
\end{tabular}


Table 4. Cooperatives' Batstone life cycle model and dynamic followed

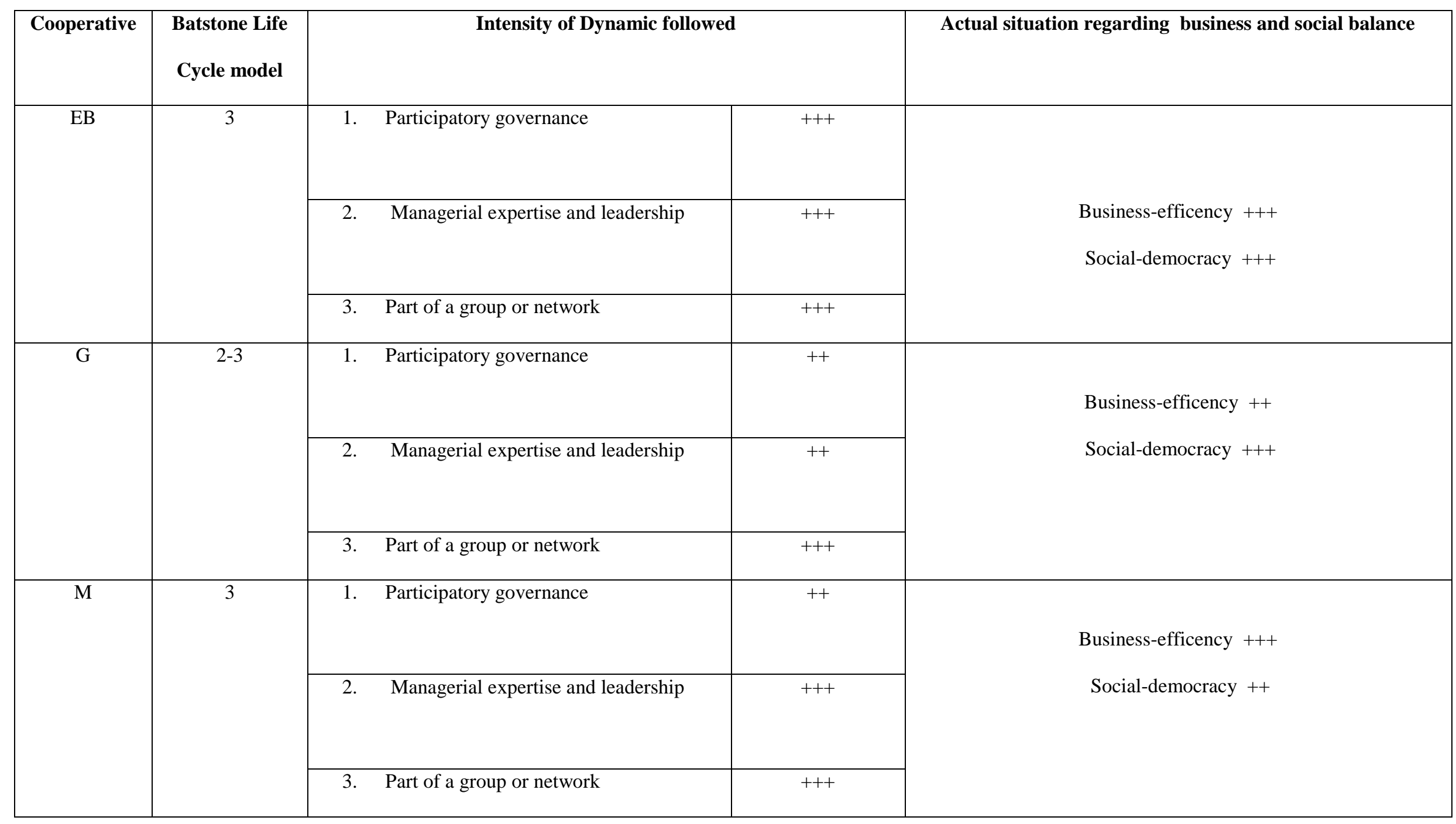




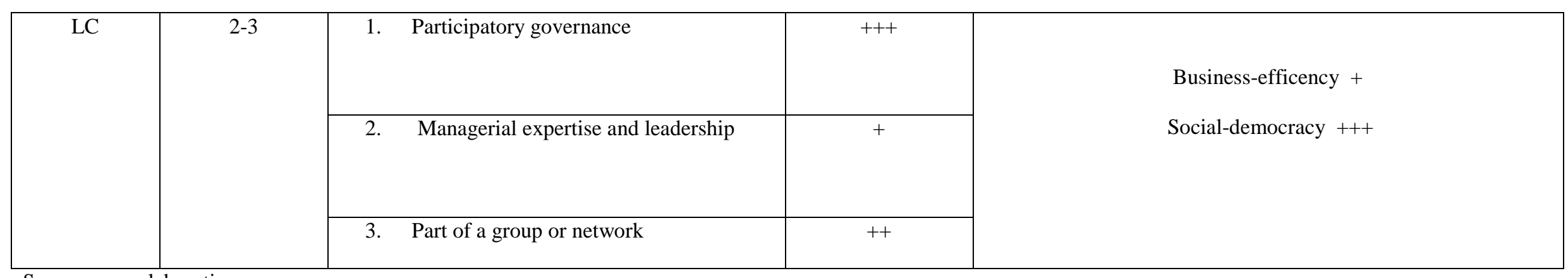

Source: own elaboration 